\title{
The Effect Of Tax Rate Change On Dividend Payout
}

George M. Jabbour, (E-mail: jabbour@gwu.edu),George Washington University Yikang Liu, ABD, (E-mail: yikang@gwu.edu), George Washington University

\begin{abstract}
President Bush's 2003 tax cut has revived the topic of dividend policy. Dividend payout depends on many factors, such as earnings, size, and growth in addition to the tax rate. To study the effect of a change in tax rates on dividends, we need to control for other factors that may affect them. Following Fama and French (2001) approach, we divide our sample firms into three different categories characterized by profitability, investment opportunity, and size; and we estimate the averaged dividend forecast errors for four groups in each category. We find size to be the most important factor related to dividends when taxes are not taken into account. In addition, empirical evidence suggests that profitability is the only factor related to dividends when tax rates are included. In other words, the more profitable the firms are, the more likely they pay higher dividends as applicable tax rates decline.
\end{abstract}

\section{Introduction}

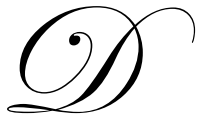

ividends are not just an outcome of a firm payout policy. Rather, they reflect a complicated combination of investment strategy, financial decision and private information (Miller and Rock 1985). From managerial perspective, dividends can serve as a tool to mitigate agency problem by digesting extra free cash flows (Jensen 1986), or to signal to the market that only good quality firms afford to pay dividends (Bhattacharya 1979). On the other hand, from the investor's perspective, dividends are beneficial since they represent a regular income stream which will enhance self-control by avoiding any irrational trades (Shefrin and Statman 1984). After the substantial dividend tax cut in $2003^{1}$, dividend-paying firms are perceived to be more in line with the interest of shareholders simply because the after-tax return of dividend-receiving investors has increased. Since dividends now are more favorable for investors under the new tax act, one question of interest is: Do firms tend to pay more dividends after tax rates are reduced? In this paper we attempt to shed a light on this issue by directly investigating the relationship between dividends and applicable tax rates. In order to identify the sole impact of taxes on dividends, we need to control for other factors. As described in Fama and French (2001), dividends reflect the characteristics of the firm especially profitability, investment opportunity, and size. After controlling for these characteristics, we find a significant negative relationship between averaged dividend forecast error and dividend tax rate for the most profitable firms. This evidence suggests that the more profitable the firms are, the more likely they pay higher dividends as applicable tax rates decline.

This paper proceeds as follows: In section 2 we review relevant studies on dividend and tax related issues. In section 3 we describe the data and methodology. In section 4 we present our results. And in section 5 we provide the conclusions.

\section{Literature review}

Before Bush's new tax act, dividends were taxed at much higher rates than capital gains. For this reason, taxable shareholders would prefer capital gains to dividends. But firms have been paying dividends. One reason could be the "bird-in-hand" approach. Another could be explained by the tax implications. Brennan (1970) predicts

\footnotetext{
${ }^{1}$ Bush's new 2003 tax act drops the top dividend tax bracket from 38.1 percent to 15 percent, the largest dividend tax cut in history.
} 
a higher pre-tax stock return to compensate shareholders for the tax disadvantage of dividends. But, Miller and Scholes (1978) argue that taxable shareholders are eventually indifferent between dividends and capital gains; and changes in tax rates will neither affect dividend policy nor the market value of the firm. The key to this "tax irrelevancy" hypothesis is the assumption that all the dividend-receiving shareholders possess the ability to transform their dividend income into capital gain by correctly adjusting their portfolios. This is consistent with the famous irrelevance of dividends in the value of the firm by Miller and Modigliani (1961) ignoring taxes in their assumptions.

At the empirical level, many studies tested the tax-effect hypothesis; but the results are inconclusive. Blume (1980) and Gordon and Bradford (1980) both find that investors dislike dividends and require compensation for receiving them. Kalay and Michaely (2000), however, find no significant difference between the risk-adjusted rates of return of high and low dividend-yield stocks. This evidence leads to the rejection of the tax-effect hypothesis. Naranjo et al (1998) find that the magnitude of the "yield effect" is too large to be explained by the tax penalty on dividend.

\section{Data and Methodology}

We use all the firms of S\&P 500, except the utility companies, for the period 1984-2002. There are 467 such firms. The main reason for choosing S\&P 500 firms is due to the fact that they are more transparent in terms of managerial decision-making. As a result, the chance of agency problem which could bias the normal standards of dividend policy is mitigated ${ }^{2}$. Utility companies are excluded because they are required by law to pay dividends.

Our goal is to find the relation between dividends and applicable tax rates. We argue that a simple regression between these two variables is not appropriate to describe such a relationship due to the following reasons: first, dividends are the outcome of many factors; and tax rate might be one of them. The simple regression between dividends and tax rates fails to capture the influence of other factors that affect dividend policy. Consequently, this approach cannot provide sufficient explanatory power to dividend policy. Second, firms tend to increase dividends over time. This increment in dividends, arising from the growth of firm size or profitability, will jeopardize the accuracy of regression outcome since the real impact of tax rate on dividends is offset by other factors. To overcome these difficulties, we treat dividends as a dynamic variable, which can be captured by profitability, investment opportunity, and size. These characteristics are identified by Fama and French (2001) and confirmed by our own logit regressions ${ }^{3}$. After controlling for these factors, we enable to estimate the relationship between dividends and tax rates. The profitability ratio (PR) for each firm is calculated by dividing its earnings before interest, tax, depreciation, and amortization (EBITDA) by its book value of total assets $(\mathrm{BV})$. The growth rate of assets, $\left(\mathrm{BV}_{\mathrm{t}^{-}}\right.$ $\left.\mathrm{BV}_{\mathrm{t}-1}\right) / \mathrm{BV}_{\mathrm{t}-1}$, is used as a proxy for the firm investment opportunity (A). The size is given by the book value of total assets (BV). All these variables are available from Compustat. The historical dividend tax rates are obtained from the Congressional Joint Committee on Taxation.

To isolate the impact of each firm characteristic on dividend, we need to break down our total samples. First we sort total samples in a descending order by profitability. Secondly, we divided the sorted samples into four groups based on the quartiles of profitability. After repeating the same data manipulation procedure under the category of investment opportunity and size respectively, we will end up with twelve groups in total. Since dividend payment is generally determined based on firm's past performance, we assume a lag effect between dividend and firm characteristics. In other words, the forecast dividend payment at time $t+1$ can be estimated by the value of profitability, investment opportunity and size at time t. We estimate the relation between dividend and firm characteristics by running cross-sectional regressions. The model is as follows:

\footnotetext{
${ }_{3}^{2}$ Refer to La Porta et al. (2000) for more details.

${ }^{3}$ The details are available upon request from the authors.
} 


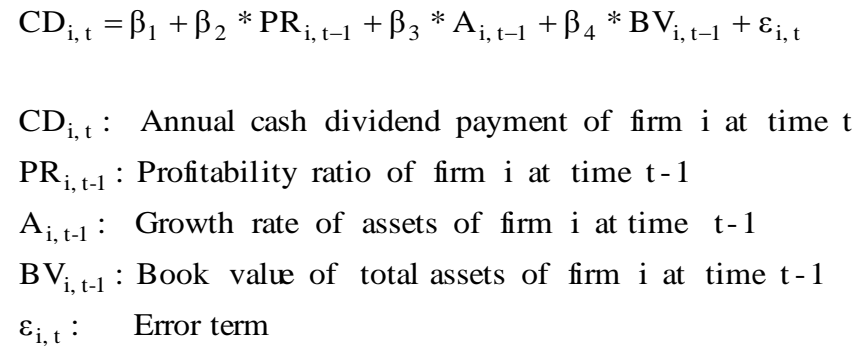

In equation (1), we estimate the $\beta$ coefficients for all twelve groups. Once the coefficients are known, we can calculate the forecast dividend of each firm i at time $t+1$ by using the following equation:

Forecast dividend $_{\mathrm{i}, \mathrm{t}+1}=\beta_{1}+\beta_{2} * \mathrm{PR}_{\mathrm{i}, \mathrm{t}}+\beta_{3} * \mathrm{~A}_{\mathrm{i}, \mathrm{t}}+\beta_{4} * \mathrm{BV}_{\mathrm{i}, \mathrm{t}}$

Since sample size in each group is observable, we can calculate the averaged forecast dividend for each group. Furthermore, we define the averaged dividend forecast error as the averaged actual dividend minus the averaged forecast dividend. The averaged dividend forecast error represents the component of firm dividend that can not be captured by firm characteristics. To find the relation between the averaged dividend forecast error and dividend tax rate we run the following regression:

$$
\text { Averaged dividend forecast error }{ }_{\mathrm{t}+1}=\alpha_{1}+\alpha_{2} * \text { dividend tax rate }_{\mathrm{t}+1}+\varepsilon_{\mathrm{t}+1}
$$

If the coefficient of the tax rate is negative then we can support the hypothesis that dividends tend to increase as tax rates decline.

\section{Results}

In summary, we sort the data by firm characteristics (profitability, investment opportunity, or size) and we classify the companies in four groups, the highest $25 \%$, the higher $50 \%$, the lower $50 \%$ and the lowest $25 \%$. There are twelve groups in total. For each group we run the regression based on equation (1) and then estimate the averaged forecast dividend and subsequently the averaged dividend forecast error. Table 1 presents the results of the OLS regressions of the averaged dividend forecast error against the applicable tax rate for each group ${ }^{4}$. To avoid any violation of the OLS regression assumptions, we apply Durbin-Watson $d$ test to examine autocorrelation and do not find any evidence of autocorrelation. In addition, we follow White's consistent covariance matrix estimators to eliminate the problem of heteroscedasticity.

For all the groups of profitability, the coefficients of the tax rate variable are, as expected, negative. They are statistically significant, however, only for the top two groups, the most profitable and profitable firms. This result is reasonable. We should not expect lower performing firms to increase their dividends as tax rates decline. They simply cannot afford it.

For the groups of investment opportunity, the coefficient of the tax rate is negative only for the lowest $25 \%$ group and it is not statistically significant. This is also understandable since companies may give priority to investment opportunities instead of paying cash dividends.

\footnotetext{
${ }^{4}$ All the regressions did not have any significant results when the samples were sorted simultaneously by more than one firm characteristic.
} 
For the groups of size, the coefficient of the tax rate is negative only for the lowest $25 \%$ group and it is not statistically significant. This could imply that smaller size firms may attempt to attract some tax-sensitive investors by increasing their cash dividends when tax rates decline. Large size companies, however, may have dividend policies insensitive to tax rate changes for different reasons such as maturity phase, traditional dividend policy, and/or type of their shareholders 5 .

\section{Table 1: Relationships Between Averaged Dividend Forecast Errors and Applicable Tax Rates}

We examine the relationships between the averaged dividend forecast errors and applicable tax rates by regressing the averaged dividend forecast errors (defined as the averaged actual dividends minus the averaged forecast dividends) against applicable tax

$$
\text { Averaged dividend forecast error }{ }_{t}=\alpha_{1}+\alpha_{2} * \text { dividend tax rate } t_{t}+\varepsilon_{t}
$$

\begin{tabular}{|c|c|c|c|c|}
\hline \multirow[b]{2}{*}{ Groups } & \multicolumn{4}{|c|}{ Estimated coefficients* } \\
\hline & $\alpha_{1}$ & t-statistic & $\alpha_{2}$ & t-statistic \\
\hline Most profitable & 61.89007 & $3.57470 * * *$ & -202.10208 & $-3.33834 * * *$ \\
\hline Profitable & 29.45818 & 2.11108 & -101.82991 & $-2.37633 * *$ \\
\hline Less profitable & -0.12565 & -0.00240 & -1.58495 & -0.01017 \\
\hline Least profitable & 41.40176 & 0.76889 & -112.97439 & -0.72844 \\
\hline Highest investment opportunities & 3.66946 & 0.04843 & 0.15114 & 0.00071 \\
\hline High investment opportunities & -21.10529 & -0.46005 & 61.17003 & 0.41954 \\
\hline Low investment opportunities & -4.55150 & -0.08392 & 29.23623 & 0.17900 \\
\hline Lowest investment opportunities & 5.43178 & 0.05097 & -22.16127 & -0.07571 \\
\hline Biggest & -72.22233 & -0.86730 & 227.01725 & 0.87944 \\
\hline Big & -55.21322 & -1.06641 & 179.83467 & 1.07192 \\
\hline Small & -9.58476 & -0.50710 & 19.45920 & 0.36735 \\
\hline Smallest & 1.76669 & 0.38627 & -8.28588 & -0.64971 \\
\hline
\end{tabular}

\section{Conclusions}

In this paper, we attempt to find the relationship between cash dividends and applicable tax rates. Since dividend policy is complex and depends on several factors, we first identified three major characteristics (profitability, investment opportunity, and size) highly related to dividends by using logit regressions. Our results

\footnotetext{
${ }^{5}$ In our logit regressions we did find that the size of the firm is the most important factor related to dividend payment. In other words, large size firms tend to pay higher dividends if tax rates are not taken into account.
} 
are consistent with those of Fama and French (2001). To control for these factors, we divide our sample into twelve groups, four for each characteristic. The results suggest that profitability is the only factor to explain the relationship between dividends and tax rates. The more profitable the firms are, the more likely they pay higher dividends as applicable tax rates decline. The implication of our findings is that, with the Bush's 2003 new tax act, the most profitable firms would increase their dividend payments.

\section{References}

1. Bhattacharya, S., 1979, "Imperfect information, dividend policy, and "the bird in the hand fallacy," Bell Journal of Economics 19, 259-270

2. Blume, M., 1980, "Stock return and dividend yield: some more evidence", Review of Economics and Statistics 62, 567-577.

3. Brennan, M., 1970, "Taxes, market valuation and corporate financial policy," National Tax Journal 23, 417-427

4. Fama, E. and K. French, 2001, "Disappearing dividends: changing firm characteristics or lower propensity to pay?" Journal of Financial Economics 60, 3-43

5. Gordon, M. and D. Bradford, 1980, "Taxation and the stock market valuation of capital gain and dividends: theory and empirical results", Journal of Public Eeconomics 14, 109-136.

6. Jensen, M., 1986, "Agency costs of free cash flow, corporate finance, and takeovers," American Economic Review 76, 323-329

7. Kalay, A. and R. Michaely, 2000, "Dividends and taxes: a re-examination", Financial Management 29 (2), 55-75.

8. La Porta, R., F. Lopez-De-Silanes, A, Shleifer and R. Vishny, 2000, "Agency problems and dividend policies around the world," Journal of Finance 55, 1-34

9. Miller, M. and F. Modigliani, 1961, "Dividend policy, growth, and the valuation of shares." Journal of Business, 411-433

10. Miller, M. and K. Rock, 1985, "Dividend policy under asymmetric information", Journal of Finance 40, 1031-1051

11. Miller, M. and M. Scholes, 1978, "Dividends and taxes," Journal of financial economics 6, 333-364

12. Naranjo, A., M. Nimalendran and M. Ryngaert, 1998, "Stock returns, dividend yields and taxes," Journal of Finance 53, 2029-2057

13. Shefrin, H. and M. Statman, 1984, "Explaining investor preference for cash dividends", Journal of Financial Economics 13, 253-282

14. White, H, 1980, "A heteroscedasticity consistent covariance matrix estimator and a direct test of heteroscedasticity," Econometrica 48, 817-818. 
$\underline{\text { Notes }}$ 